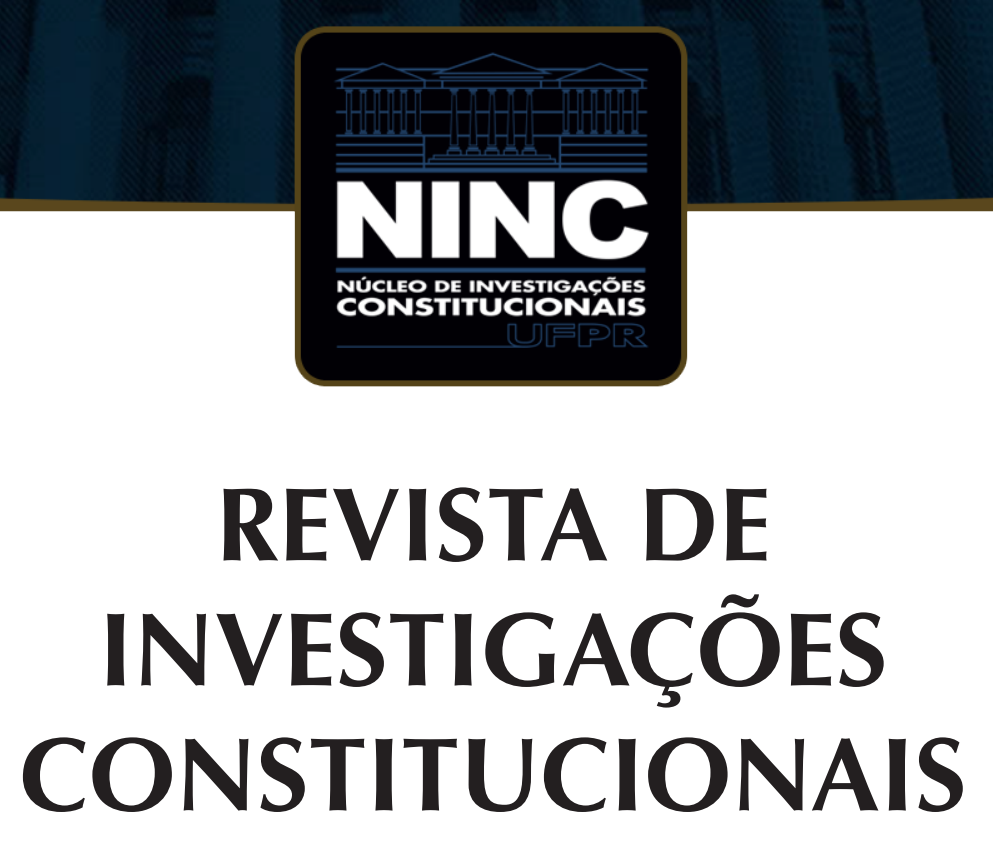

JOURNAL OF CONSTITUTIONAL RESEARCH

vol. 8 | n. 1 | janeiro/abril 2021 | ISSN 2359-5639 | Periodicidade quadrimestral Curitiba | Núcleo de Investigações Constitucionais da UFPR | www.ninc.com.br 


\title{
Democracy, fundamental rights and public finance: a constitutionalist criticism of the Steuerle-Roeper Index
}

\section{Democracia, direitos fundamentais e finanças públicas: uma crítica constitucionalista ao índice Steuerle-Roeper}

\author{
FRANCISCO MATA MACHADO TAVARES ${ }^{\text {1, * }}$ \\ ' Universidade Federal de Goiás (Goiânia, Goiás, Brasil) \\ franciscotavares@ufg.br \\ https://orcid.org/0000-0002-3905-8141 \\ Recebido/Received: 09.04.2020 / April 09 ${ }^{\text {th }}, 2020$ \\ Aprovado/Approved: $22.10 .2020 /$ October $22^{\text {th }}, 2020$
}

\section{Abstract}

The article proposes to critically discuss the concept of fiscal democracy as operationalized by the means of the Steuerle-Roeper Index. It is assumed that the contemporary sociohistorical context comprises a scenario of crisis or decline of democracies, largely explained by the fiscal difficulties faced by the States. The Fiscal Democracy Index is discussed as a promising scientific contribution for the attribution of empirical tangibility to such a reality. However, a difficulty is identified concerning the non-consideration of fundamental rights as condition for the possibility of democratic politics. Finally, an example from the Brazilian constitutional system is presented in order to illustrate the article's theoretical argument.

Keywords: fundamental rights; fiscal democracy; fisca rigidity; Steuerle-Roeper Index; crítica constitucionalista.
Resumo

O artigo propõe-se a discutir criticamente o conceito de democracia fiscal, tal como operacionalizado por meio do Índice Steuerle-Roeper. Assume-se que o contexto sócio-histórico contemporâneo compreende um cenário de crise ou declínio das democracias, amplamente explicado pelas dificuldades fiscais enfrentadas pelos Estados. O Índice de Democracia Fiscal é discutido como uma contribuição científica promissora para a atribuição de tangibilidade empírica a esta realidade. Contudo, identifica-se uma dificuldade, concernente à não consideração dos direitos fundamentais como condições de possibilidade da política democrática. Finalmente, um exemplo proveniente do sistema constitucional brasileiro é apresentado para fins de ilustrar o argumento teórico do artigo.

Palavras-chave: direitos fundamentais; democracia fiscal; rigidez fiscal; Índice Steuerle-Roeper; constitutionalist criticism.

Como citar esse artigo/How to cite this article: TAVARES, Francisco Mata Machado. Democracy, fundamental rights and public finance: a constitutionalist criticism of the Steuerle-Roeper Index. Revista de Investigações Constitucionais, Curitiba, vol. 8 , n. 1, p. 161-183, jan./abr. 2021. DOI: 10.5380/rinc.v8i1.72768.

" Professor adjunto na Universidade Federal de Goiás (Goiânia-GO, Brasil). Docente permanente do Programa de Pós-graduação em Direitos Humanos (mestrado e doutorado). Doutor em Ciências Políticas pela Universidade Federal de Minas Gerais. E-mail: franciscotavares@ufg.br. 


\section{CONTENTS}

1. Introduction; 2. The Fiscal Dimension of Democracy and Fundamental Rights; 3. Democracy in Numbers: Potentials of the Fiscal Democracy Index in the "Age of Austerity"; 4. The Steuerle-Roeper Index Difficulties under a Constitutionalist Look: About the Nexus Between Constitutional and Budgetary Rigidity; 5. Fiscal Rigidity, Democracy and Fundamental Rights in the Brazilian Legal System: The Case of Social Security; 6. Conclusion; 7. References.

\section{INTRODUCTION}

Social conflict over public finances is central to the sociogenesis of the modern State ${ }^{1}$. Thus, the construction of bridges between the theory of fundamental rights and democratic theory, from the socio-fiscal perspective ${ }^{2}$, is promising for both subdisciplines. Moved by this spirit, this article critically discusses an increasingly influential concept in contemporary political theory, in the light of conceptions shared by liberal and deliberationist streams of constitutional and democratic theory regarding the normative restraint of political-decision-making processes. The argument that is intended is that, contrary to what is shown in the literature associated with the concept of fiscal democracy ${ }^{3}$, the constitutional rules that establish forms of budgetary rigidity do not necessarily imply the mitigation of democratic political processes. More specifically, the theoretical problem to be solved is formulated in the following question: are the theoretical bases of the notion of fiscal democracy and the index that algebraically operationalizes it compatible with the relationship between democracy and law inscribed in the liberal and deliberationist streams of contemporary constitutionalism?

To clarify this question, the second section, presented bellow, indicates how democratic theory and contemporary constitutionalism are anchored in the public finance

\footnotetext{
See: SCHUMPETER, J. The Crisis of the Tax State. In: SWEDBERG, R. (Org.). Joseph A. Schumpeter: The Economics and Sociology of Capitalism Princeton: Princeton UP, 1991, p. 99 - 140; GOLDSCHEID, Rudolf. A Sociological Approach to Problems of Public Finance. In: MUSGRAVE, Richard; PEACOCK, Alan T (Org.). Classics in the Theory of Public Finance. London: MacMillan, 1958, p. 202-213; HOFFMAN, Phillip T; NORBERG, Kathryn Norberg. Fiscal Crises, Liberty and Representative Government: 1450-1789. Stanford: Stanford UP, 1994, p. 1-7; TILLY, Charles. State, Taxes and Proletarians. CRSO Working Papers, [s.I.], vol. 213, 1980, p. 17-22. Disponível em: https://deepblue.lib.umich.edu/bitstream/handle/2027.42/50987/213.pdf?sequence=1\&isAllowed=y ELIAS, Norbert. The Civilizing Process: Sociogenetic and Psychogenetic Investigations. Malden: Blackwell Publishing, 2000, p.344-362; MARTIN, Isaac Willian; MHEROTRA. Ajay K; PRASAD; Monica. The Thunder of History. In: MARTIN, Isaac Willian; MHEROTRA. Ajay K; PRASAD; Monica (Org.). The New Fiscal Sociology: Taxation in Comparative and Historical Perspective. New York: Cambridge UP, 2009, p. 1-28.

2 BACKHAUS, Jürgen G. Fiscal Sociology: What for? In: BACKHAUS, Jürgen G.; WAGNER, Richard E (Org.). Handbook of Public Finance. London: Springer, 2002. p. 521-542.

3 STEUERLE, Eugene. Restoring Fiscal Democracy. The Milken Institute Review, 1st Quarter, 2016, p. 26-35. Disponível em: https://www.urban.org/sites/default/files/publication/80326/2000781-Restoring-Fiscal-Democracy.pdf. Acesso em: 10 de julho de 2017. STREECK, Wolfgang; MERTENS, Daniel. An Index of Fiscal Democracy, MPIFG Working Paper, [s.I.], vol. 10, n. 03, abr. 2010, p. 6-8. Available at: https://www.mpifg.de/pu/workpap/ wp10-3.pdf; GENSCHEL, Philipp; SCHWARZ, Peter. Tax Competition and Fiscal Democracy. In: STREECK, W; SCHÄFER, A. (Org.). Politics in the Age of Austerity. Cambridge: Polity, 2013, p. 59-83. p. 59-83.
} 
field. The third section then discusses the decline or atrophy of democratic regimes in the global context after the 2008 crisis and introduces the Fiscal Democracy Index (or Steuerle-Roeper Index) ${ }^{4}$, as proposed by Steuerle ${ }^{5}$ in the United States of America and applied in Germany by Streeck and Mertens ${ }^{6}$, as a potentially promising tool in the empirical measurement of the phenomenon. The fourth section, in turn, suggests that despite the unambiguous methodological and empirical performance associated with the Fiscal Democracy Index, its theoretical foundations severely compromise the goal of algebraic synthesizing of the atrophy of democratic regimes. These shortcomings will be observed under the premise - shared between liberal and deliberationist conceptions of constitutionalism - that there is a complementarity between fundamental rights and democracy that can, on occasion, support the linking or pre-allocation of expenditure in public budgets. Finally, before the final considerations, I present a case of compatibility between compulsory spending and democratic decision-making, extracted from the Brazilian social security legal regime.

\section{THE FISCAL DIMENSION OF DEMOCRACY AND FUNDA- MENTAL RIGHTS}

The main theories of democracy established throughout the twentieth century, as well as a significant portion of contemporary constitutionalist thinking, are anchored in elements linked to public finances. The following examples - pointillist and lacking in systematization - justify this premise, from which arises the problem that drives the theoretical research reported here.

Contemporary democratic theory has as its axis or gravitational framework the work of J. Schumpeter, in which subsequent contributions tend to establish relationships of ratification, complementation, or criticism. ${ }^{7}$ What is less discussed in the literature is the fact that the procedural and methodological notion of democracy formulated by the Triesch-born economist ${ }^{8}$ corresponds to a state idea based on the essential tax relation established between the subject as taxpayers and the sovereign power as collector.

\footnotetext{
4 The index is named after economists Eugene Steuerle and Timothy Roeper. Only the first one, however, signs the publications on the subject, in which it is reported that he contributed to the creation of the index.

5 STEUERLE, Eugene. Restoring Fiscal Democracy. The Milken Institute Review, 1st Quarter, 2016, p. 26-35. Disponível em: https://www.urban.org/sites/default/files/publication/80326/2000781-Restoring-Fiscal-Democracy.pdf. Acesso em: 10 de julho de 2017.

6 STREECK, Wolfgang; MERTENS, Daniel. An Index of Fiscal Democracy, MPIFG Working Paper, [s.I.], vol. 10, n. 03, abr. 2010. Disponível em https://www.mpifg.de/pu/workpap/wp10-3.pdf, p. 59-83.

7 SHAPIRO, Ian. The State of Democratic Theory. In: KATZNELSON, Ira; MLNER, Helen V. (Org.). Political Science: State of the Discipline. New York: Norton, 2002, p. 235-236.

8 SCHUMPETER, Joseph A. Capitalism, Socialism and Democracy. New York: Harper Perennial, 2008.
} 
In 1918, under declared influence of the sociology of public finance launched by Goldscheid ${ }^{9}$, Schumpeter formulated the idea that the modern state would be better defined as a Tax State. From examples linked mainly to Prussian history, it was pointed out that the processes of states consolidation and control of the respective rulers (historical anteroom of democratization) obeyed conflicts referred to in the state collection. The tax relation has been postulated as the "thunder of history," from which all symbolic and material aspects of societies could be explained, either causally or symptomatically. ${ }^{10}$ In short, the primal reference of contemporary democratic theory is the work of the same thought and creative flow that laid the foundations of fiscal sociology and gave public finance a central role in explaining political relations and conflicts in advanced capitalism.

A second and relevant example is to be found in Anthony Downs's work, whose content has greatly influenced contemporary studies of political science by presenting an effort to transpose the method and theoretical framework of neoclassical economics into the framework of political relations in representative democracies. Anchored in ideas such as "personal interest axiom" and "utility calculations" as driving forces of action in society, Downs presents a procedural notion of democracy, in which the central element, explicitly mentioned in seven of the eight conditions for a democratic government listed by the author, lies in elections.."11

Although the book "An Economic Theory of Democracy" receives considerable attention in the literature - to this day still informing theoretical and empirical studies with their considerations on electoral behavior, logic of governmental action and definition of democratic governments - that fact that soon after its publication Downs had complemented it is often overlooked. In an article published in the World Politics in 1960 , the author used his theoretical and methodological toolkit to present two ideas that tie his democratic theory to the scope of public finance:

i. Downs has stated that the way governments make their spending, once referenced in the scope of raising votes in the upcoming elections, relates to the electorate's perceptions of the impact that taxation has on their lives in relation to the benefits they perceive from the actions of the state. Taxes and budgets would, in effect, be the skeleton of electoral processes and the actions of incumbents in power.

ii. Even more emphatically, the political theorist concludes that "each national election can be considered a contest between two prospective government

9 GOLDSCHEID, Rudolf. A Sociological Approach to Problems of Public Finance. In: MUSGRAVE, Richard; PEACOCK, Alan T (Org.). Classics in the Theory of Public Finance. London: MacMillan, 1958, p. 202-213.

10 SCHUMPETER, J. The Crisis of the Tax State. In: SWEDEBERG, Richard (Org.). Joseph A. Schumpeter: The Economics and Sociology of Capitalism. Princeton: Princeton UP, 1991, p. 99-140.

11 DOWNS, Anthony. An Economic Theory of Democracy. New York: Harper \& Row, 1957, p. 23-24. 
budgets".12 This argument is of unique relevance to a debate on fiscal rigidity. Now, if democracy corresponds to elections and these to budgetary fluctuations, then it is worth discussing the hypothesis that policies of fiscal rigidity mitigate the scope for public spending to obliquely affect or even nullify the meaning of electoral disputes, so as to make the democratic regime itself unfeasible.

Public finances also feature prominently in critical and normative theories about democracy. As with orthodox and descriptive variants, this trait is not usually noted with the expected prominence. Take, for example, the theory of deliberative democracy, which in its origin largely constitutes a Habermasian response to the socio-historical context named by the Frankfurt philosopher, even in his writings of the 1970s, "legitimation crisis in late capitalism." This crisis would occur in countries that established welfare states in Western Europe, in the midst of which it had been proven politically difficult over time to resolve the tension between capitalism and democracy with the arrangement that "is supposed to raise the requisite amount of taxes by skimming off profits and income and to use the available taxes so rationally that crisis-ridden disturbances of growth can be avoided". ${ }^{13}$ If the prelude to deliberative democracy was the Habermasian diagnosis of a fiscal crisis demanding additional legitimacy for taxation, the present moment of the author's philosophical-political production focuses on the problems of the European Union. It, according to Habermas, would be hijacked by an undemocratic technocracy. The proposed solution, as if rediscovering the problem of previous decades, would be found in three elements, all somewhat associated with public finances, which should be democratically coordinated throughout the Old Continent: (i) fiscal, economic and monetary policy; (ii) budget policy, and; (iii) public debt. ${ }^{14}$ The socio-historical diagnosis in which deliberative democracy flourishes, therefore, refers to the centrality of fiscal issues, both at their earliest origin and today.

Another example deserves mention before addressing the relationship between constitutionalism and taxation. Studies on the history of democracies, especially on democratization and de-democratization processes, are centrally referenced in aspects such as taxes and budgets, especially with regard to the need for those under the jurisdiction to acquiesce to increasing revenue, in order to enable expenditures worthy of the efforts of wars or conquests in which National States were born. ${ }^{15}$ The most influential reference in explaining the mechanisms that inform the birth and fall

\footnotetext{
12 DOWNS, Anthony. Why the Government Budget is too Small in a Democracy. World Politics, [s.l.], vol. 12, n. 4, p. 541-563, 1960, p. 545.

13 HABERMAS, Jürgen. Legitimation Crisis. Cambridge: Polity Press, 1992. p. 62.

14 HABERMAS, Jürgen. The Lure of Technocracy. Cambridge: Polity Press, 2015, p. 9.

15 HOFFMAN, Phillip T; NORBERG, Kathryn Norberg. Fiscal Crises, Liberty and Representative Government: 1450-1789. Stanford: Stanford UP, 1994, p. 299-312.
} 
of democracies in comparative experience, Charles Tilly, focuses closely on the conflicts associated with state extraction, the most notable of which being taxation. The author asserts that extraction "opens the way to new citizen-state bargains that subject states to public politics and facilitate popular influence over public politics. To that extent it promotes democratization over the long run"16. Extractive demands of states would operate according to cycles of intervention - resistance - repression - bargaining / democratization. ${ }^{17}$

The examples above are enough to justify the argument that taxation is, in the history of modern democracy and the theories aimed at justifying or depicting it, more than an incidental element. A similar line of reasoning can be lent to fundamental rights, which are quintessential pillars of contemporary state in the same degree that democracy is. Notwithstanding this common "tax-dependence", the connections between rights and taxes are not so linear or clear as they are with democracy. In fact, different theoretical approaches to the nature and types of fundamental rights could lead to a comprehension of tax that oscilates from an intrusion on property against which the first constitutional guarantees had emerged, to an apparently antagonistic view, regarding taxation as necessary condition for the rights effectiveness.

A traditional and still influential stream of the theoretical production devoted to contemporary constitutional law supports a typology of fundamental rights according to which there would be "positive" or "prestational" norms demanding state actions and expenditures, alongside "negative" or "defensive" precepts, whose deontological sense would lie in the wake of the anti-absolutist auspices that drove the eighteenth-century revolutions into omissions and not state interventions. Ran Hirschl thus summarizes this distinction: "negative rights consist of fundamental freedoms (like freedom of speech, religious tolerance, freedom from arbitrary arrest and so on). Positive rights traditionally consist, inter alia, of social rights such as the universal right to services meeting basic human needs (e.g., health care, basic housing, education, social security and welfare, and an adequate standard of living). The term "positive rights" is often used to describe these basic social rights, since they require the state to act positively to promote the well-being of its citizens, rather than merely refraining from acting"18.

The cleavage between prestational and defense rights could be problematic from the perspective of public finances. Positive rights would rely on tax revenues and, in some sense, the more the state could collect from its citizens, the more resources to

16 TILLY, Charles. Democracy. Cambridge: Cambridge University Press, 2007, p. 142.

17 TILLY, Charles Tilly. Extraction and Democracy. In: MARTIN, Isaac Willian; MHEROTRA. Ajay K; PRASAD; Monica (Org.). The New Fiscal Sociology: Taxation in Comparative and Historical Perspective. New York: Cambridge UP, 2009, p. 173-182.

18 HIRSCHL, Ran. "Negative" Rights vs. "Positive" Entitlements: A Comparative Study of Judicial Interpretations of Rights in an Emerging Neo-Liberal Economic Order. Human Rights Quarterly, [s.I.], vol. 22, n. 4, p. 10601098, 2000, p. 1071. 
public policies aimed at providing housing, social security, public education and other social rights would be availabe. On the other hand, a constitutional scheme equipped with rigid limits to taxation (and, thus, a set of "negative" rules for the protection of private property), would, hypothetically, be more compatible with the so-called first generation rights. Such a logic, in the limit, could suggest crises. ${ }^{19}$ This would be because the absolute restraint of taxation (paroxysm rights of defense) would lead to zero ground for the effectiveness of positive rights or a context of debt so intense that it would dissolve the Schumpeterian tax state into the debt state described by Streeck, ${ }^{20}$ where the interests of creditors would take precedence over fundamental rights or democratic decisions.

It is possible, however, to go beyond this record and to argue that, as with the processes of state-building and democratization, the themes linked to public accounts are indecomposable from the whole debate about fundamental rights, which, in addition to the typologies that define them as "defense" or "performance", they all reap the same deontological dignity. In this spirit, two books published at the beginning of the 21 st century and written under the influence of liberalism are especially relevant.

Under the tax approach, L. Murphy and T. Nagel proposed that it makes no normative sense to affirm the notion of a "tax burden" or a "pre-tax income", to be protected as a "defense" in the face of state taxation. ${ }^{21}$ On the one hand, from the factual and economic point of view it is true that the modern state funds itself by extracting portions of private productive activity, governed by free enterprise and not directly controlled by bureaucracy. ${ }^{22}$ On the other hand, property is, rather than a fact of nature or a gift with metaphysical genesis, a proclaimed right, prescribed and guaranteed precisely by the state. Thus, the state consistently precedes property in a logical-legal approach, so that taxation cannot be understood merely as an immersion of sovereign power in an outside domain and for which it should, in principle, be omitted. ${ }^{23}$ Ownership, in its modern expression, associated with free enterprise and private choices about production, stems from a state-political environment that is indispensable for its recognition and maintenance.

\footnotetext{
19 Hoffman and Norberg's concept of fiscal crisis, in fact, concerns a framework in which there is a leap in public spending beyond the State's ability to raise and borrow.

20 STREECK, Wolfgang. Buying Time: The Delayed Crisis of Democratic Capitalism. London: Verso, 2014.

21 MURPHY, Liam; NAGEL, Thomas Nagel. The Myth of Ownership: taxes and justice, Oxford: Oxford University Press, 2005.

22 OFFE, Claus. Theses on the Theory of the State. In: KEANE, John (Org.). Contradictions of the Welfare State. London: Hutchinson, 1984, p. 120-121.

23 See: "Tax policy analysis needs to be emancipated from everyday libertarianism; it is an unexamined and generally non-explicit assumption that does not bear examination, and it should be replaced by a concept of property rights as depending on the legal system that defines them. Since that system inludes taxes as an absolute essential part, the idea of prima facie property right in one's pretax income - an income that could not exist without a tax-supported government - is meaningless" (MURPHY, Liam; NAGEL, Thomas Nagel. The Myth of Ownership: taxes and justice, Oxford: Oxford University Press, 2005, p. 36.)
} 
More recently, a depiction of capital, rather than just property, as a product of law, in contrast with a "pure" economic fact, was developed by Katharina Pistor. The legal theorist argues that wealth is the outcome of a legal codification, whose fundamental modules (property, contracts, bankruptcy, trusts and corporations) foster a set of privileges to an asset's holder, related to law's recognition of the asset's priority, durability, convertibility and universality. All that legal codification is backed by the state's coercive powers ${ }^{24}$. It seems to tacitly ratify the thesis that state precedes wealth and, coherently, tax comes before property, leading to the conclusion that the state positive performance in creating and protecting property is undetachable to its later "negative" non-intervention on it. A theory of fundamental rights grounded on this ideas would probably reinforce Nagel's and Murphy's arguments about property and taxes.

Thus, before "negative" rights, every constitutional guarantee, no matter how liberal its remote origin may be, depends on a materially equipped and well maintained state apparatus that, under conditions of advanced capitalism, gathers its material conditions for operation mainly through tax collection. The same state that relies on private production and the consent of the courts to collect the taxes that maintain it is the one that recognizes, guarantees and protects property. Therefore, there would be no normative precedence between the areas of private production / accumulation of wealth and extraction / taxation by the Government. In short, there would be no fundamental rights without the state, and there would be no constitutional state without taxes.

Similar logic, but focused on public spending, is found in the theory of rights formulated by S. Holmes and C. Sunstein, to whom there are no "negative rights". Every legislative prescription, according to the argument and the myriad of historical examples mobilized to back it, however classified as omissive, reflects state costs and expenditures. Freedom of movement would at least require state authority to ensure some safety on the itineraries; freedom of expression presupposes the regulation of conduct such as slander and injury; property would need coercive remedies to protect it and courts to settle conflicts over it, and so on. Every right costs and is positive in the Holmes and Sustein theory. Therefore, there is no constitutional provision exempt from tangible projection in the public budget. ${ }^{25}$

\footnotetext{
24 PISTOR, Katharina. The Code of Capital: how the law creates wealth and inequality. Princeton: Princeton University Press, 2019.

25 HOLMES, Stephen; SUNSTEIN, Cass. The Cost of Rights: why liberty depends on taxes. New York: Norton \& Company, 1999. In the same sense, an excerpt from an anthological article by J. Waldron, published even before Holmes and Sunstein's book: "All serious political theorists recognize that protection is costly, and that therefore first generation - as much as economic entitlements - impose costs and raise questions about priorities for us all". (WALDRON, Jeremy. Liberal Rights: Collected Papers 1981-1999. Cambridge: Cambridge UP, 1993).
} 
As the examples addressed below suggest, a vast and influential portion of democratic theory and constitutional law theory, therefore, not only establishes a dialogue with the field of public finance, but are materially grounded in conflicts and decisions regarding taxation and the budget. Thus, the idea of creating an index that, based on public account numbers, measures the scope for the implementation of democratic decisions in each country, seems promising. The budgetary availability annually linked to the decision of the parliament representatives would in principle be the measure of the material extension of the democratic process and the promulgation or maintenance of rights.

This is precisely the proposal launched by Eugene Steuerle, a celebrated economist from the US, who held the presidency of the National Tax Association between 2001 and 2002. ${ }^{26}$ With emphasis on the theoretical concept of fiscal democracy, which refers to the availability of resources for rulers and parliamentarians instead take different courses of action, the author created, in collaboration with NYU economics professor Timothy Roeper, the Fiscal Democracy Index, or the Steuerle-Roeper Index. The initiative, however, finds its weaknesses when compared with an understanding of fundamental rights and democracy as equiprimordial. In the following sections, the characteristics of the index and their possible limits are more closely investigated.

\section{DEMOCRACY IN NUMBERS: POTENTIALS OF THE FISCAL DEMOCRACY INDEX IN THE "AGE OF AUSTERITY"}

Contemporary democracies, especially following the unfolding of the economic crisis that erupted in 2008, are precarious with regards to the means to implement citizens' decisions in representative or participatory forums. Depleted, states can follow the exchange of rulers and political groups in the government posts (arche) without, however, finding ways to do things ( $\left.\operatorname{kratos}^{27}\right)$ in accordance with the wishes, preferences and choices expressed by citizens in electoral processes or social participation mechanisms ${ }^{28}$.

The main challenge faced by contemporary constitutuional and democratic regimes is no longer the elections or the possibilibity of public opinion's influence on legislative procedures, but the avaiability of resources to fund its outcomes. A portent of such a historic scenario is the way how, rectifying his own theory of late capitalism's

26 STEUERLE, Eugene C. Dead Men Ruling: How to Restore Fiscal Freedom and Rescue our Future. New York: The Century Foundation Press, 2014, p. 1-18.

27 Further considerations on the meaning of the Greek terms "arche" and "kratos" can be found in OBER, Josiah. The Original Meaning of "Democracy: Capacity to Do Things, not Majority Rule". Constellations, [s.l.], vol. 15, n. 1, p. 3-9, 2008.

28 SCHÄFFER, Armin; STREECK, Wolfgang. Introduction: Politics in the Age of Austerity. In SCHÄFFER, Armin; STREECK, Wolfgang (Org.). Politics in the Age of Austerity. Cambridge: Polity Press, 2013, p. 1-25. 
social crisis, Jürgen Habermas has recently written that "today we are not (yet?) experiencing a legitimation crisis, but we are witnessing a palpable economic crisis" 29 . The theme is recurrent in numerous theoretical and empirical contributions published since 2008.

Schäfer and Streeck find a decrease in electoral participation in the Global North, associated with the increase of state indebtedness, the maturation of the welfare state and the increase of public debts, in a context they define as "the age of austerity". An apathetic electoral behavior would be manifested especially among people with less education and income, indicating a consequence of a scenario constituted by a demos in the absence of kratos.

Offe starts from the same empirical observation (drop in voter turnout under austerity policies) and rescues the political thinking of Schattschneider, a political scientist whose work, still in the mid-twentieth century, pointed out that the less privileged strata no longer participate in the elections less for coercive reasons, but above all because they feel that their voices would not even be heard, regardless of the candidates in which they voted. ${ }^{30}$ On this basis, Offe notes that the problem of contemporary democracies lies more in the supply of policies and rights in accordance with popular choices (kratos) than in the demand carried by means such as elections, protests and public opinion manifestations (demos). ${ }^{31}$

With a focus on collective action and the paradoxical accentuation - at least in the Global North - of both protest and political apathy, Donatella Della Porta adjusts the Habermasian theory of crisis to the present reality and realizes that if, at the apex of the Social State, the political conflict would be related to the need for growing legitimacy for bureaucracies that increasingly intervened in society, the problems nowadays unfold from the alienation of the State, which is less capable in the midst of indebtedness, loss of revenue, deregulation of economic activities and privatization..$^{32}$ In this context, a "crisis of political responsibility" emerges, in which the jurisdictions tend to lose confidence in the States, which would negatively impact democracies.

This decline in democratic regimes as a problem associated with the fiscal inability of indebted states and entangled in practices that erode their tax bases, such as tax

\footnotetext{
29 HABERMAS, Jürgen. The Lure of Technocracy. Cambridge: Polity Press, 2015, p. 85.

30 OFFE, Claus. Participatory Inequality in the Austerity State: a supply side approach. In: SCHÄFER, Armin \& STREECK, Wolfgang (Org.). Politics in the age of austerity. Cambridge: Polity Press, 2013.

31 Colin Hay notes that the equation of this debate according to the demand and supply categories is valid, but tends to be compressed in narrowly economistic terms. See: HAY, Colin. Why We Hate Politics. Cambridge: Polity, 2007. Hence the choice in this article for demos and kratos in the definition rescued by Josiah Ober, "The Original Meaning of Democracy".

32 DELLA PORTA, Donatella. Social movements in times of austerity: bringing capitalism back into protest analysis. Cambridge: Polity press, 2015, p. 110-156.
} 
competition, ${ }^{33}$ leading elections to lose their ability to impact governments to become anodyne spectacles, ${ }^{34}$ is fit for the development of some empirical measurement that estimates it quantitatively.

This is the scope of the Fiscal Democracy Index, whose premise is that democratic regimes "begin to creak and function poorly when previous decisions by dead or retired policymakers effectively curtail today's and future generations of the power to make their own decisions". ${ }^{35}$ The vicious cycle, from a democratic perspective, would lie in a prolonged granting of rights associated with upward spending and tax favors that lead the state to increased indebtedness. The present generations would be reduced to the condition of public debts payers, stripped of the possibility of influencing the direction of governments through their electoral manifestations.

Thought from the perspective of the United States's public budget law, the index is algebraically intuitive and, according to its formulator, would have the merit of political neutrality, since it would consider both tax benefits (usually adopted by the right) and social rights (usually preferred by the left). Its formula is as follows: 1- [(compulsory expenditures + interest on public debt) / income], multiplied by one hundred, for percentage conversion. ${ }^{36}$ Revenue decreases and increases in compulsory spending have, as it turns out, the same effect on reducing fiscal democracy as Steuerle conceived.

The previous section substantiated the theoretical premise that political-democratic and legal-constitutional conflicts comprise a necessary fiscal dimension. Thus, the contemporary debate on the crisis of constitutional democracies can be observed from public finances. This option has a triple potential: (i) from the theoretical point of view, it brings together the constitutional and political discussions of the taxation and budget realms, so as to allow an interdisciplinary connection between State, society and economy in social research; (ii) in a methodological dimension, the identification of problems in democratic regimes based on data emanating from public finances gives scientific research an objective view as much as possible, allowing for greater tangibility

33 OECD (Organization for Economic Co-operation and Development). Harmful Tax Competition: an emerging global issue, 1998, disponível em <https://www.oecd.org/tax/transparency/44430243.pdf> Acesso em 10/09/2018; GENSCHEL, Philipp; SCHWARZ, Peter. Tax Competition and Fiscal Democracy. In: STREECK, W; SCHÄFER, A. (Org.). Politics in the Age of Austerity. Cambridge: Polity, 2013, p. 59-83; DIETSCH, Peter; RIXEN, Thomas. Tax Competition and Global Background Justice. In: GOODIN, Robert E.; FISHKIN, James S. (Org.). Political Theory Without Borders. Sussex: Willey, 2016, p. 77-106.

34 CROUCH, Collin. Post-Democracy. Cambridge: Polity press, 2004.

35 STEUERLE, Eugene C. Dead Men Ruling: How to Restore Fiscal Freedom and Rescue our Future. New York: The Century Foundation Press, 2014, p. 8.

36 The index formula, in its algebraic expression, does not appear in any Eugene Steurle publication. Streeck and Mertens present it and report in a statement that they got the information through personal communication with the US economist. See: STREECK, Wolfgang; MERTENS, Daniel. Public Finance and the Decline of State Capacity in Democratic Capitalism. In: SCHÄFER, Armin \& STREECK, Wolfgang (Org.). Politics in the age of austerity. Cambridge: Polity Press, 2013, p. 26-58. 
to diagnoses of the demos' weakening power in today's societies, and; (iii) as for the empirical aspect, it is obtained with the abundance, comparability and availability of data on taxes and budgets. ${ }^{37}$ The work developed by Steuerle regarding the reality of the United States and adapted by Streeck and Mertens ${ }^{38}$ for Germany apparently contemplates these attributes to bring about a scientific contribution capable of algebraically simplifying and exposing in precise and easy to understand numbers the legal-political moment in which States prove to be materially incapable to operate in accordance with the collective will when it comes to promoting public policies or securing fundamental rights. ${ }^{39}$

The Fiscal Democracy Index imparts empirical and methodological transparency to the diagnosis of States surrendered to the primacy of "permanent austerity".40 Their numbers, in fact, show a reduction in the discretionary margin of governments, with a drop of more than 40 percentage points in Germany and more than 60 in the US between 1970 and 2010.41

For political science, it is a precise indicator of the democratic decline within the Kratos, that is, the ability of collective decisions to be implemented. For constitutional law, it is a tangible and operable framework for informing dogmatic and hermeneutic debates about notions such as "reserve of possible" and "existential minimum." There are, however, limitations and shortcomings in the formulation as outlined below.

\section{THE STEUERLE-ROEPER INDEX DIFFICULTIES UNDER A CONSTITUTIONALIST LOOK: ABOUT THE NEXUS BETWE- EN CONSTITUTIONAL AND BUDGETARY RIGIDITY}

The preceding section presented the Fiscal Democracy Index as a tool capable of methodologically and empirically assisting the theoretical discussion of the problems

\footnotetext{
37 MARTIN, Isaac Willian; MHEROTRA. Ajay K; PRASAD; Monica. The Thunder of History. In: MARTIN, Isaac Willian; MHEROTRA. Ajay K; PRASAD; Monica (Org.). The New Fiscal Sociology: Taxation in Comparative and Historical Perspective. New York: Cambridge UP, 2009, p. 1-27.

38 STREECK, Wolfgang; MERTENS, Daniel. Public Finance and the Decline of State Capacity in Democratic Capitalism. In: SCHÄFER, Armin \& STREECK, Wolfgang (Org.). Politics in the age of austerity. Cambridge: Polity Press, 2013, p. 26-58.

39 STEUERLE, Eugene. Restoring Fiscal Democracy. The Milken Institute Review, 1st Quarter, 2016, p. 26-35. Disponível em: https://www.urban.org/sites/default/files/publication/80326/2000781-Restoring-Fiscal-Democracy.pdf. Acesso em: 10 de julho de 2017.

40 See: "Changes in the global economy, the sharp slowdown in economic growth, the maturation of governmental commitments, and population ageing all generate considerable fiscal stress. There is little reason to expect these pressures to diminish over the next few decades. If anything, they are likely to intensify." PIERSON, Paul. Coping With Permanent Austerity Welfare State restructuring in Affluent Democracies. In: PIERSON, Paul (Org.). The New Politics of the Welfare State. New York: Oxford University Press, 2001, p. 411.

41 STREECK, Wolfgang; MERTENS, Daniel. An Index of Fiscal Democracy, MPIFG Working Paper, [s.l.], vol. 10, n. 03, abr. 2010, p. 6-8. Disponível em: https://www.mpifg.de/pu/workpap/wp10-3.pdf.
} 
faced by democratic regimes in times of permanent austerity. There is, however, an omission in the index's theoretical assumptions, whose apparent face is a myopia in the theory of fundamental rights. This problem compromises both the heuristic potential and the explanatory capacity of the numbers generated on the basis of the formula proposed by Steuerle, which influences studies in economics, public policy and even critical political science of notable European intellectuals, such as Wolfgang Streeck and Daniel Mertens, or Philip Genschel and Peter Schwarz. ${ }^{42}$

As we have seen, the numerator of Steuerle's formula comprises indiscriminately government debt and other compulsory expenditure. This equation is anchored in theoretical difficulties that compromise it empirically and methodologically. Suppose, for example, that a central bank insulated from demos-franchised accountability decides, less for strictly technical reasons and more for economic and political interests of the financial sector, to increase the interest premium paid for the purchase of government bonds. ${ }^{43}$ In such a scenario, any reduction in social rights spending to meet the increased cost of debt service would be neutral from the perspective of the Fiscal Democracy Index. Taking the argument to its extreme, it is noted that a country where the entire budget is devoted to compulsory social security spending is as democratic as that which brings all the amounts collected with the payment of interest decided in spaces impervious to participation, representation or influence of the demos.

The relationship between numerator and denominator of the index also carries difficulties. Take, for example, a country that significantly reduces taxes on mobile bases and, as a result of the loss of revenue, also compromises social expenditures, keeping the debt servicing amounts constant. The index is not sensitive in relation to these changes in taxation, as long as they are offset by the reduction in mandatory spending. Thus, the vast empirical evidence and historical narratives about the impact of tax increase as an independent variable in democratization processes are diregarded. ${ }^{44}$

The theoretical flaw that produces the distortions identified above rests on the failure to consider, in the elaboration of the index, a common idea of modern constitutionalism, according to which the fundamental rights are precisely what is subtracted from the ordinary democratic contentions.

42 STREECK, Wolfgang; MERTENS, Daniel. An Index of Fiscal Democracy, MPIFG Working Paper, [s.l.], vol. 10, n. 03, abr. 2010, p. 6-8. Disponível em: https://www.mpifg.de/pu/workpap/wp10-3.pdf; GENSCHEL, Philipp; SCHWARZ, Peter. Tax Competition and Fiscal Democracy. In: STREECK, W; SCHÄFER, A. (Org.). Politics in the Age of Austerity. Cambridge: Polity, 2013, p. 59-83.

43 In Brazil, the political and economic interests, before an anodyne technical logic, influencing the fixing of the basic interest rate was discussed and sufficiently evidenced by Daniel Bin. See: BIN, Daniel. Macroeconomic Policies and Economic Democracy in Neoliberal Brazil. Ecomomia e Sociedade, Campinas, vol. 24, n. 33, p. 513-539, 2015.

44 BASKARAN, Tushyantan. Taxation and Democratization. World Devolpment, v. 56, issue C, p. 287-301, 2014. 
The relationship between fundamental rights and democracy informs a relentless debate in the legal and political thinking of modernity. The pre-political nature of the natural property right grounded by Locke lays the foundation for the liberal emphasis on normative arrangements in relation to political processes. ${ }^{45}$ The thesis that the constitutive pact of political power is preceded by rights already present in the state of nature resonates in later times with the idea that constitutional predictions conform to aspects of sociability subtracted from democratic decision-making rites or, at least, subject to stricter procedural requirements for their promulgation or amendment.

Accordingly, in "A Theory of Justice", Jonh Rawls had established, between topics 36 and 38, the philosophical-legal bases of the liberal-egalitarian conception of constitutionalism. ${ }^{46}$ The theme is taken up by the author in "Political Liberalism", when discussing the special relevance of fundamental freedoms. ${ }^{47}$ The argument of the Neo-contractualist philosopher, who builds a conception of justice based on the counterfactual notions of original position and veil of ignorance, is that, in favor of priority due to freedom, any restrictions on the right to political participation - for example, by means of greater rigidity in their procedures on fundamental issues - is justifiable. On Hobbesian anthropo-philosophical grounds in this regard, Rawlsian liberalism postulates that a harmonious society must admit that individuals have no confidence in the fulfillment of norms by others, unless a central and legitimate authority is established to coercively ensure them in favor of all. Admittedly, this authority must not rise to the point of becoming tyrannical and suppressing the very freedom that the compliance to rules allows to maintain and prosper. The relationship between the principle of equal political participation and juridical-constitutional constraints reveals itself as a specific variation of this larger theme, concerning the composition between individual free will, responsibility towards oneself and others, distrust and stabilization of relations by legal-coercive means.

Stephen Holmes goes on to note that protector-bound norms such as constitutional rigidity go beyond, securing other freedoms of a non-political or participatory order. In fact, they allow the democratic process itself to be recognized, enhanced and legitimized. An example mobilized by the jurist and politologist in question is limited to freedom of communication and expression, whose social and deontological meaning reverberates over the conditions of political participation and thus enhances democracy itself. Provisions rigidly protected against the will of the volatile majorities can, rather than safeguard, boost democracy, as they give the decision-making process confidence and the conditions for eventual decision-making failures occurring today to be

45 LOCKE, John. Second Treatise of Government. Indianapolis: Hackett Publishing Company, 1980.

46 RAWLS, John. A Theory of Justice. Cambridge: Belknap Press, Harvard University Press 1999, p. $194-213$.

47 RAWLS, John. Political Liberalism. New York: Columbia University Press, 1993. 
corrected tomorrow. A fallibilist notion of democracy, therefore, preserves the elements (such as rights of opposition and freedom of criticism, in a more obvious example) with which what is decided today may eventually be rectified tomorrow. The effect of this arrangement is greater confidence in democratic processes and thus the strengthening of this political regime. ${ }^{48}$

In other words, Stephen Holmes bases the thesis that the legal stiffening of the democratic process (used by the author around the tension between the passions of citizens and the necessary constraints of the social order) not only harmonizes other freedoms (those that Constant would define as modern ones) with political freedoms, but promotes and strengthens them. The normative rigidity and the issuing of commands that forbid or limit eventual debates in political-representative scope are opportunizing elements, rather than reducers, of democratic regimes.

If constitutionalism and the rigidity of legal norms are already understood as driving forces of democracy within the framework of liberalism, this conception deepens into the Habermasian philosophical body, from which the deliberative normative model of democracy is built upon. Deliberative democracy, at least in its earliest formulations, can be understood as a continuity, within the realm of the law and political philosophy, of the great philosophical project woven by Habermas in his "The Theory of Communicative Action". Here the Frankfurt philosopher sought to compose a Weberian diagnosis of social rationalization under modern conditions with a civilizational orientation towards the Marxian horizon of emancipation as nonreification and an influence of the philosophy of language on the construction of a philosophical anthropology on the basis of which work gives ground to symbol-mediated interactions as a distinctive feature of humanity. The social conflict fitting to late capitalism would lie not between capital and labor, but between a free domain of informal communication and not driven by means, which Habermas engages with a redefined view of the Husserlian concept of lifeworld (Lebenswelt) and the field of interactions, codified by the means of power or money, which lies in a redefinition of the Parsonian meaning of system. Despite the potential for interactions between free and equal people in life-world, in conditions of social complexity inherent in modernity, societies need to rely on generalized forms of reduction that ensure material (economy) and social (State) reproduction. The colonization imposed by the logic of the systems on the communicative webs of the life-world compresses, however, the rationality in means-end rational action, trimming that which is human from what defines it, namely the ability to establish communicative practices driven only by the non-coercive force of the best argument, and validated

48 HOLMES, Stephen. Passions and Constraints: On the Theory of Liberal Democracy Chicago: Chicago UP, 1995. 
according to the demands from the sincerity of the sender, the truth of the statement and the normative adequacy in the bond established with the receiver. ${ }^{49}$

In "Between Facts and Norms," Habermas advances on the above summarized philosophical project and finds in law the attribute of a hinge, a connecting element between system and life-world. In this arrangement, the communicative flows emanating from the former it arrive at the logic of the latter, either for the regulation of the economy or the conformation of the bureaucratic activity of the State, by means of law. This is the element that prevents both chaotic communicative overload in the lifeworld and human reification in the strategic rationality of systems.

In the same effort, Habermas, consistent with the pragmatist legacy about his ideas, seeks to find a conception of political-legal subjectivity that seems equidistant between what he understands as a liberal self-contradictory individualism and an ethical overload proper to republican collective subjectivities.$^{50}$

On this philosophical-political ground, the thesis of the equiprimordiality between fundamental rights (which Habermas understands as expressions of private autonomy) and democracy (which the author associates with public autonomy and popular sovereignty) thrives. Oblivious to all naturalistic metaphysics and ethically overburdened notions of general will, Habermas acknowledges that the foundation of the legitimacy of democratic decisions lies in the fact that they are proliferated in a deliberative setting established between free and equal citizens who recognize themselves as such, so that "when citizens occupy the role of co-legislators they are no longer free to choose the medium in which alone they can realize their autonomy. They participate in legislation only as legal subjects".51 On the other hand, it is postulated, to the detriment of heteronomous determinations, that "the democratic procedure (...) alone provides legitimating force to the law".52 The author admits a circularity in the way in which he bases fundamental rights and democracy, but asserts that this is the only non-metaphysical way to legitimately postulate the political and normative ordering of plural and complex societies. ${ }^{53}$ Rigid fundamental rights, in short, are not restrictive factors, but conditions of possibility for democratic regimes. In conclusion, the leader of deliberative democracy states that "without basic rights that secure the private autonomy

49 HABERMAS, Jürgen. The Theory of Communicative Action. vol. 2: Lifeworld and System. Boston: Beacon Press, 1987. HABERMAS, Jürgen. The Theory of Communicative Action. vol. 1: Reason and Rationalization of Society. Boston: Beacon Press, 1984.

50 HABERMAS, Jürgen. Between Facts and Norms: contributions to a discourse theory of law and democracy. Cambridge: MIT Press, 1996.

51 HABERMAS, Jürgen. The Inclusion of The Other: Studies in Political Theory. Cambridge: The MIT Press, 1998, p. 260.

52 HABERMAS, Jürgen. The Inclusion of The Other: Studies in Political Theory. Cambridge: The MIT Press, 1998, p. 259.

53 HABERMAS, Jürgen. Concluding comments on empirical approaches to deliberative politics. Acta Politica, [s.l.], vol. 40, p. 384-392, 2005. 
of citizens there is also no medium for legally institutionalizing the conditions under which these citizens, as citizens of a state, can make use of their public autonomy." ${ }^{54}$

The Fiscal Democracy Index is short-sighted to the debate above. Now, if all fundamental rights, as justified in the preceding section, are necessarily and by definition projected at the level of public budgets, then the expected rigidity of constitutional norms must also resonate with regard to fiscal hardening, that is, the normative definition, preferably in constitutional matters, of compulsory expenses allocated to the costing of the most prestigious rights by the legal system. Thus, linking spending in fields such as education, health, and welfare - fundamental rights like any other, once the above-discussed Holmes and Sunstein theory has been adopted — are a driving force, rather than a limit to democracy.

To equate expenditures with public debt remuneration with budgetary allocations aimed at funding social, civil or political rights, as if they were all restrictions to democracy, clashes with the vast juridical-philosophical grounding on fundamental rights as conditions for the possibility of democracy, as formulated from the liberalism to deliberative democracy.

Brazilian constitutional law contains, for the purpose of this debate, an emblematic example, as developed in the following section.

\section{FISCAL RIGIDITY, DEMOCRACY AND FUNDAMENTAL RI- GHTS IN THE BRAZILIAN LEGAL SYSTEM: THE CASE OF SOCIAL SECURITY}

The debate about the theoretical problems of the Fiscal Democracy Index, resulting from a myopia regarding the understanding of the mutual presupposition between democracy and fundamental rights, is clearer when discussed with reference to positive Brazilian constitutional law.

Unlike the US reality, which is the basis of Steuerle's elaboration, the constitutionalized budgetary law in Brazil does not take the compulsory expenses away from democratic scrutiny in Parliament or in participatory spaces. It is precisely because fundamental rights and democracy propel each other that the institutional imagination can go beyond the proposal of the suppression of social security rights or the diagnosis of "maturation of the Welfare State", when it has to do with reconciling compulsory spending with popular sovereignty. ${ }^{55}$

\footnotetext{
54 HABERMAS, Jürgen. The Inclusion of The Other: Studies in Political Theory. Cambridge: The MIT Press, 1998, p. 261.

55 STEUERLE, Eugene C. Dead Men Ruling: How to Restore Fiscal Freedom and Rescue our Future. New York: The Century Foundation Press, 2014, p. 1-18; Schäfer and Streeck, "Politics in the Age of Austerity", 1-25.
} 
Take the example of Brazilian social security. On the one hand, there is a finalistic aspect in the commandment of the tax norms referring to the taxes defined in article 195 of the Constitution as directed to the funding of fundamental rights such as health, social security and social assistance..$^{56}$ On the other hand, this tightening of the budget does not preclude, with the assurance of resources without which the elderly, the sick and those who are in conditions of poverty could not even operate in the public sphere in conditions of parity, the establishment of a democratic discussion on expenses associated with the theme. There is, as stated in Article 165, paragraph 5, III of the Constitution, a social security budget, discussed by the Parliament. In fact, once the budget in question is defined by the elected Legislative Houses, their management follows a participatory logic, counting on representatives of workers, employees, retirees and government, organized in councils, as determined by article 194, VII of the Constitution. This Brazilian constitutional arrangement, with all its nuances and complexities, escapes the Steuerle-Roeper index, which, short-sighted on fundamental rights theory, understands that social security rights and interest payments on public debt are equal, under the condition of compulsory spending as limiting factors of democracy.

The bottom line of liberal and deliberative constitutionalism is that in a country where the elderly have no security in their livelihoods, the sick do not know whether they will be able to afford the costs to be treated and the most vulnerable ones live below the minimum material conditions to assure their dignity, the private autonomy of the individuals that make up these groups is undermined to the extent that it makes the constitution of a democratic public space composed of free and equal persons unfeasible. What Brazilian law adds to the debate is the creativity of constitutional engineering that, while maintaining the mandatory nature of some expenses, opens the representative or participatory public scene for them to be allocated and managed democratically. The following considerations compose this example with the theoretical critique of the Steuerle-Roeper Index, in dialogue with a social ontology proper to the "age of austerity", developed by Streeck. ${ }^{57}$

\section{CONCLUSION}

Today's State lives under "permanent austerity." In a context in which Schumpeter's dax State gives way to the debt State described by Streeck, democratic politics and constitutional arrangements referenced in fundamental rights seem at risk. ${ }^{58}$ The

56 SPAGNOL, Werther Botelho. As Contribuições Sociais no Direito Brasileiro. Rio de Janeiro: Forense, 2002.

57 SCHÄFFER, Armin; STREECK, Wolfgang. Introduction: Politics in the Age of Austerity. In SCHÄFFER, Armin; STREECK, Wolfgang (Org.). Politics in the Age of Austerity. Cambridge: Polity Press, 2013, p. 1-25; STREECK, Wolfgang. Buying Time: The Delayed Crisis of Democratic Capitalism. London: Verso, 2014, p. 46-96.

58 STREECK, Wolfgang Streeck, Buying Time: The Delayed Crisis of Democratic Capitalism. London: Verso, 2014, p. 46-96. 
idea of measuring the atrophy of democracies by quantifying the unavailability of fiscal resources for the implementation of decisions preferred by citizens / voters seems methodologically blissful in this context. The theoretical concept of fiscal democracy and its operationalization in an index that gives it empirical maneuverability offer, indeed, important tools for contemporary legal and social research. By not paying attention to the equiprimordiality between democracy and fundamental rights, however, the proposal becomes unsuccessful and falls into a blind spot that prevents it from dealing with arrangements such as the Brazilian social security, by equalizing all sorts of mandatory expenditure under the sign of the threat to democracy.

Before concluding, it turns out that there is a deeper theoretical explanation why fundamental rights and debt spending cannot be exchanged. Paradoxically, it is W. Streeck, a thinker who has adapted the Fiscal Democracy Index to the German reality, who provides the elements to explain this point. As seen in the previous section, in the work of Habermas there is no need to talk about democracy but in a society in which people are constituted as subjects of rights. Streeck, in his studies of the age of austerity, understands that the relationship established between state and creditors is ontologically distinct, since they do not engage in a democratic game. The subjects of law would integrate a social base defined by the author as "people's constituency" or "Staatsvolk". Creditors, on the other hand, would make up the "market constituency" or "Marktvolk". 59 The differences between these social bases are set out below.

Markets operate internationally and peoples are limited to borders. Markets have investors as their analytical unit who act as creditors, while peoples rely on citizens, who act mainly as voters. Markets claim credit prerogatives over public debt securities and peoples crave citizenship rights. Markets are continually heard in audiences and people are mainly listened to through elections. Markets influence political decisions by fluctuating interest rates, while people do so by public opinion. Markets evaluate the state based on its ability to honor debt service, before guaranteeing rights such as health, education, transportation and housing. ${ }^{60}$

The theoretical track that leads from Holmes's constitutional and legal philosophy and follows through Habermas, addressed in the fourth section, to arrive at Streeck's social ontology, mentioned above, indicates that relations between subjects of law and State can be democratized and harmonized, with measures of constitutional rigidity aimed at guaranteeing fundamental rights. The Brazilian legal system attests to this possibility, as seen in the social security regime.

59 STREECK, Wolfgang Streeck, Buying Time: The Delayed Crisis of Democratic Capitalism. London: Verso, 2014, p. 81.

60 STREECK, Wolfgang Streeck, Buying Time: The Delayed Crisis of Democratic Capitalism. London: Verso, 2014, p. 79-90. 
The bond between State and creditors, on the other hand, is ontologically distinct and cannot be democratized or associated with the preservation of fundamental rights. Debt service and the costing of rights through fiscal hardening are not, therefore, equal obstacles to democracy, as Steuerle suggests with the Fiscal Democracy Index. ${ }^{61}$

Finally, the idea of composing an index that indicates the atrophy of sovereign powers in contexts of fiscal crisis, to the detriment of democracy, is salutary. This endeavor, however, must take into account the relationship of mutual determination between public and private autonomy, so as not to reduce the theoretical status of expenditures and fundamental rights to the same level as the payment of interest on public debt decided in insulated and hermetically separated agencies from instruments of vertical or social accountability. An interdisciplinary challenge to the sciences of economics, law and politics may, in fact, lie in constructing an index that circumvents the theoretical limits pointed out here in the Steuerle-Roeper Index.

\section{REFERENCES}

BACKHAUS, Jürgen G. Fiscal Sociology: What for? In: BACKHAUS, Jürgen G.; WAGNER, Richard E (Org.). Handbook of Public Finance. London: Springer, 2002.

BASKARAN, Tushyantan. Taxation and Democratization. World Development, [s.I.], vol. 56, issue C, p. 287-301, 2014.

BIN, Daniel. Macroeconomic Policies and Economic Democracy in Neoliberal Brazil. Ecomomia e Sociedade, Campinas, vol. 24, n. 33, p. 513-539, 2015.

CROUCH, Collin. Post-Democracy. Cambridge: Polity press, 2004.

DELLA PORTA, Donatella. Social movements in times of austerity: bringing capitalism back into protest analysis. Cambridge: Polity press, 2015.

DIETSCH, Peter; RIXEN, Thomas. Tax Competition and Global Background Justice. In: GOODIN, Robert E.; FISHKIN, James S. (Org.). Political Theory Without Borders. Sussex: Willey, 2016.

DOWNS, Anthony Downs. An Economic Theory of Democracy. New York: Harper \& Row, 1957.

DOWNS, Anthony. Why the Government Budget is too Small in a Democracy. World Politics, [s.l.], vol. 12, n. 4, p. 541-563, 1960.

ELIAS, Norbert. The Civilizing Process: Sociogenetic and Psychogenetic Investigations. Malden: Blackwell Publishing, 2000.

61 STEUERLE, Eugene. Restoring Fiscal Democracy. The Milken Institute Review, 1st Quarter, 2016, p. 26-35. Disponível em: https://www.urban.org/sites/default/files/publication/80326/2000781-Restoring-Fiscal-Democracy.pdf. Acesso em: 10 de julho de 2017. 
GENSCHEL, Philipp; SCHWARZ, Peter. Tax Competition and Fiscal Democracy. In: STREECK, W; SCHÄFER, A. (Org.). Politics in the Age of Austerity. Cambridge: Polity, 2013, p. 59-83.

GOLDSCHEID, Rudolf. A Sociological Approach to Problems of Public Finance. In: MUSGRAVE, Richard; PEACOCK, Alan T (Org.). Classics in the Theory of Public Finance. London: MacMillan, 1958.

HABERMAS, Jürgen. Between Facts and Norms: contributions to a discourse theory of law and democracy. Cambridge: MIT Press, 1996.

HABERMAS, Jürgen. Concluding comments on empirical approaches to deliberative politics. Acta Politica, [s.l.], vol. 40, p. 384-392, 2005.

HABERMAS, Jürgen. Legitimation Crisis. Cambridge: Polity Press, 1992.

HABERMAS, Jürgen. The Inclusion of The Other: Studies in Political Theory. Cambridge: The MIT Press, 1998.

HABERMAS, Jürgen. The Lure of Technocracy. Cambridge: Polity Press, 2015.

HABERMAS, Jürgen. The Theory of Communicative Action. vol. 1: Reason and Rationalization of Society. Boston: Beacon Press, 1984.

HABERMAS, Jürgen. The Theory of Communicative Action. vol. 2: Lifeworld and System. Boston: Beacon Press, 1987.

HAY, Colin. Why We Hate Politics. Cambridge: Polity, 2007.

HIRSCHL, Ran. "Negative" Rights vs. "Positive" Entitlements: A Comparative Study of Judicial Interpretations of Rights in an Emerging Neo-Liberal Economic Order. Human Rights Quarterly, [s.I.], vol. 22, n. 4, p. 1060-1098, 2000.

HOFFMAN, Phillip T; NORBERG, Kathryn Norberg. Fiscal Crises, Liberty and Representative Government: 1450-1789. Stanford: Stanford UP, 1994.

HOLMES, Stephen. Passions and Constraints: On the Theory of Liberal Democracy Chicago: Chicago UP, 1995.

HOLMES, Stephen; SUNSTEIN, Cass. The Cost of Rights: why liberty depends on taxes. New York: Norton \& Company, 1999.

LOCKE, John. Second Treatise of Government. Indianapolis: Hackett Publishing Company, 1980. MARTIN, Isaac Willian; MHEROTRA. Ajay K; PRASAD; Monica. The Thunder of History. In: MARTIN, Isaac Willian; MHEROTRA. Ajay K; PRASAD; Monica (Org.). The New Fiscal Sociology: Taxation in Comparative and Historical Perspective. New York: Cambridge UP, 2009.

MURPHY, Liam; NAGEL, Thomas Nagel. The Myth of Ownership: taxes and justice, Oxford: Oxford University Press, 2005. 
OBER, Josiah. The Original Meaning of "Democracy: Capacity to Do Things, not Majority Rule". Constellations, [s.I.], vol. 15, n. 1, p. 3-9, 2008.

OECD (Organization for Economic Co-operation and Development). Harmful Tax Competition: an emerging global issue, 1998, disponível em <https://www.oecd.org/tax/transparency/44430243.pdf> Acesso em 10/09/2018.

OFFE, Claus. Participatory Inequality in the Austerity State: a supply side approach. In: SCHÄFER, Armin \& STREECK, Wolfgang (Org.). Politics in the age of austerity. Cambridge: Polity Press, 2013.

OFFE, Claus. Theses on the Theory of the State. In: KEANE, John (Org.). Contradictions of the Welfare State. London: Hutchinson, 1984.

PIERSON, Paul. Coping With Permanent Austerity Welfare State restructuring in Affluent Democracies. In: PIERSON, Paul (Org.). The New Politics of the Welfare State. New York: Oxford University Press, 2001.

PISTOR, Katharina. The Code of Capital: how the law creates wealth and inequality. Princeton: Princeton University Press, 2019.

RAWLS, John. A Theory of Justice. Cambridge: Belknap Press, Harvard University Press 1999.

RAWLS, John. Political Liberalism. New York: Columbia University Press, 1993.

SCHÄFFER, Armin; STREECK, Wolfgang. Introduction: Politics in the Age of Austerity. In SCHÄFFER, Armin; STREECK, Wolfgang (Org.). Politics in the Age of Austerity. Cambridge: Polity Press, 2013.

SCHUMPETER, J. The Crisis of the Tax State. In: SWEDEBERG, Richard (Org.). Joseph A. Schumpeter: The Economics and Sociology of Capitalism. Princeton: Princeton UP, 1991.

SCHUMPETER, Joseph A. Capitalism, Socialism and Democracy. New York: Harper Perennial, 2008.

SHAPIRO, Ian. The State of Democratic Theory. In: KATZNELSON, Ira; MLNER, Helen V. (Org.). Political Science: State of the Discipline. New York: Norton, 2002.

SPAGNOL, Werther Botelho. As Contribuições Sociais no Direito Brasileiro. Rio de Janeiro: Forense, 2002.

STEUERLE, Eugene C. Dead Men Ruling: How to Restore Fiscal Freedom and Rescue our Future. New York: The Century Foundation Press, 2014.

STEUERLE, Eugene. Restoring Fiscal Democracy. The Milken Institute Review, 1st Quarter, 2016, p. 26-35. Disponível em: https://www.urban.org/sites/default/files/publication/80326/2000781 -Restoring-Fiscal-Democracy.pdf. Acesso em: 10 de julho de 2017.

STREECK, Wolfgang Streeck. Buying Time: The Delayed Crisis of Democratic Capitalism. London: Verso, 2014. 
STREECK, Wolfgang; MERTENS, Daniel. An Index of Fiscal Democracy, MPIFG Working Paper, [s.I.], vol. 10, n. 03, abr. 2010.

STREECK, Wolfgang; MERTENS, Daniel. Public Finance and the Decline of State Capacity in Democratic Capitalism. In: SCHÄFER, Armin \& STREECK, Wolfgang (Org.). Politics in the age of austerity. Cambridge: Polity Press, 2013.

TILLY, Charles Tilly. Extraction and Democracy. In: MARTIN, Isaac Willian; MHEROTRA. Ajay K; PRASAD; Monica (Org.). The New Fiscal Sociology: Taxation in Comparative and Historical Perspective. New York: Cambridge UP, 2009.

TILLY, Charles. Democracy. Cambridge: Cambridge University Press, 2007.

TILLY, Charles. State, Taxes and Proletarians, CRSO Working Papers, [s.I.], vol. 213, 1980.

WALDRON, Jeremy. Liberal Rights: Collected Papers 1981-1999. Cambridge: Cambridge UP, 1993. 